\title{
Profitability of Integrated Management of Fusarium Head Blight in North Carolina Winter Wheat
}

\author{
Christina Cowger, Randy Weisz, Consuelo Arellano, and Paul Murphy
}

First author: United States Department of Agriculture-Agricultural Research Service, Department of Plant Pathology; second and fourth authors: Crop Science Department; and third author: Statistics Department, North Carolina State University, Raleigh 27695. Accepted for publication 30 March 2016.

\begin{abstract}
Cowger, C., Weisz, R., Arellano, C., and Murphy, P. 2016. Profitability of integrated management of Fusarium head blight in North Carolina winter wheat. Phytopathology 106:814-823.

Fusarium head blight (FHB) is one of the most difficult small-grain diseases to manage, due to the partial effectiveness of management techniques and the narrow window of time in which to apply fungicides profitably. The most effective management approach is to integrate cultivar resistance with FHB-specific fungicide applications; yet, when forecasted risk is intermediate, it is often unclear whether such an application will be profitable. To model the profitability of FHB management under varying conditions, we conducted a 2-year split-plot field experiment having as main plots highyielding soft red winter wheat cultivars, four moderately resistant (MR) and three susceptible (S) to FHB. Subplots were sprayed at flowering with Prosaro or Caramba, or left untreated. The experiment was planted in seven North Carolina environments (location-year combinations); three were irrigated to promote FHB development and four were not irrigated. Response variables were yield, test weight, disease incidence, disease severity, deoxynivalenol (DON), Fusarium-damaged kernels, and percent infected kernels. Partial

profits were compared in two ways: first, across low-, medium-, or highDON environments; and second, across environment-cultivar combinations divided by risk forecast into "do spray" and "do not spray" categories. After surveying DON and test weight dockage among 21 North Carolina wheat purchasers, three typical market scenarios were used for modeling profitability: feed-wheat, flexible (feed or flour), and the flour market. A major finding was that, on average, MR cultivars were at least as profitable as $\mathrm{S}$ cultivars, regardless of epidemic severity or market. Fungicides were profitable in the feed-grain and flexible markets when DON was high, with MR cultivars in the flexible or flour markets when DON was intermediate, and on $\mathrm{S}$ cultivars aimed at the flexible market. The flour market was only profitable when FHB was present if DON levels were intermediate and cultivar resistance was combined with a fungicide. It proved impossible to use the risk forecast to predict profitability of fungicide application. Overall, the results indicated that cultivar resistance to FHB was important for profitability, an FHB-targeted fungicide expanded market options when risk was moderate or high, and the efficacy of fungicide decision-making is reduced by factors that limit the accuracy of risk forecasts.
\end{abstract}

Fusarium head blight (FHB, or scab) of wheat (Triticum aestivum) and barley (Hordeum vulgare) is a much-studied disease that lowers grain yield and contaminates grain with mycotoxins such as deoxynivalenol (DON). In the United States, the disease is mainly caused by Fusarium graminearum (teleomorph Gibberella zeae), a fungal pathogen with a wide host range. The U.S. Food and Drug Administration has set $2 \mu \mathrm{g} \mathrm{g}^{-1}$ as the advisory ceiling for DON in wheat grain and $1 \mu \mathrm{g} \mathrm{g}^{-1}$ as the ceiling for DON in wheat flour (McMullen et al. 1997).

In wheat, extruded anthers are the primary infection site (Parry et al. 1995). Anther infections often result in lack of kernel development, while slightly later infections lead to shriveled DONcontaining kernels (Fusarium-damaged kernels [FDK]) and still later infections can result in apparently sound kernels that nonetheless are infected and contain mycotoxins (Cowger and Arellano 2010; Del Ponte et al. 2007; Hart et al. 1984; Schmale and Bergstrom 2003). Winter wheat remains vulnerable to FHB and mycotoxin development up to 10 days after mid-flowering (Cowger and Arellano 2010). Postanthesis moisture tends to increase DON and FDK (Cowger et al. 2009). Using three soft red winter wheat (SRWW) cultivars in four seasons, Salgado et al. (2015)

Corresponding author: C. Cowger; E-mail address: Christina.Cowger@ars.usda.gov

*The $\boldsymbol{e}$-Xtra logo stands for "electronic extra" and indicates that one supplementary file is published online.

http://dx.doi.org/10.1094/PHYTO-10-15-0263-R

This article is in the public domain and not copyrightable. It may be freely reprinted with customary crediting of the source. The American Phytopathological Society, 2016. estimated the effect of each percent increase in disease index (percent diseased spike area) as 2.3 to $3.2 \mathrm{~kg} \mathrm{~m}^{-3}$ in test weight (TW) and $51.7 \mathrm{~kg} \mathrm{ha}^{-1}$ in yield.

In the United States, forecasts of FHB risk are available for spring or winter wheat in 31 states at a national FHB Prediction Center (www.wheatscab.psu.edu). The spring wheat model takes variety resistance into account, and this feature was made publicly available in the winter wheat model in 2015. Risk of an epidemic with greater than $10 \%$ field severity (= index) is estimated based on relative humidity (RH). The models are reported to be accurate about $75 \%$ of the time (www.wheatscab.psu.edu/model_basics).

Based on 12 years of data from national multilocation uniform fungicide trials in 14 U.S. states, the most effective fungicides for suppressing scab were identified, in order of efficacy, as metconazole (Caramba; BASF, Durham, NC), prothioconazole (Proline; Bayer Crop Science, Research Triangle Park, NC), and prothioconazole + tebuconazole (Prosaro; Bayer Crop Science) (Paul et al. 2010). Overall, there was a significant mean increase in yield of 13.8 to $15.0 \%$ but only a 2.5 to $2.8 \%$ mean increase in TW. Fungicide benefits were greater for spring wheat than for winter wheat. For SRWW, there was a larger mean increase (7 to 22\%) in yield when index was high (30\%) but only a modest yield increase (3 to $8 \%$ ) at a low disease index (5\%), implying that the profitability of fungicide application may be most uncertain when forecasted scab intensity is mild to moderate.

A meta-analysis of over 40 trials from 12 northern and Midwestern U.S. states showed that the combination of moderately resistant (MR) cultivars and a single Prosaro application at anthesis was one of the most yield-stabilizing management approaches across environments when compared with the absence of either or both management tools (Willyerd et al. 2012). An additive effect was found for fungicide 
and resistance on both index and DON, and the percent control of index with fungicide was often lower on MR than on susceptible (S) cultivars. The majority of the trials $(72 \%)$ used SRWW cultivars; none occurred in the Mid-Atlantic or Southeast regions.

None of the research reported above explored economic return; thus, more information is needed to help guide winter wheat producers in deciding when scab-specific fungicide applications will be profitable, especially given the difficulty of making effective applications at the optimal time. In particular, questions often arise in borderline situations (e.g., whether a net profit will result from spraying an MR cultivar when risk is moderate). Factors that must be taken into account include costs of fungicide ground applications, which include yield lost due to flattening by spray equipment; prices of the fungicides most effective against scab, which are relatively high; variations in wheat prices; and varying DON and TW dockage rules dependent on grain market type.

A 2-year experiment was conducted in North Carolina to address the profitability of this "integrated management" approach (use of FHB resistance, fungicides, or both) with varying environments and degrees of FHB severity. Our main objective was to determine the impact of FHB resistance or fungicide use on grain yield, TW, DON, and partial profit associated with three typical grain markets in the southeastern United States. Secondarily, after the field experiment was conducted, we sought to determine the economics associated with fungicide applications triggered by real-time predictions of FHB severity using the Prediction Center risk assessment tool (www. wheatscab.psu.edu).

\section{MATERIALS AND METHODS}

The overall approach was as follows: the study was based on a multilocation field experiment in which cultivars with differing levels of FHB resistance were exposed to varying levels of FHB severity. FHB-related data were collected, including symptoms, yield, and grain quality. Grain purchasers in the geographic area surrounding the study locations were interviewed to gather information on wheat prices and FHB dockage practices. Costs of fungicide application were estimated based on relevant factors. All these data were used to estimate partial profits under different degrees of FHB pressure when using the two primary techniques of integrated FHB management: cultivar resistance and fungicide applications. Finally, the FHB risk assessment tool was used to determine whether a fungicide would have been recommended for each cultivar in each environment, following the rule of thumb of applying a fungicide unless forecasted risks were low, and profitability of spraying versus not spraying was calculated for each cultivar-location combination.

Field experiment location and design. There were seven experimental environments, two in 2009-10 and five in 2010-11, hereafter referred to as 2010 and 2011, respectively (Table 1). The environments spanned a range of growing conditions. Four were in commercial production fields and three were on research stations. Three environments were irrigated to enhance FHB levels, while four were not. The two Monroe environments were in no-till production with substantial maize residue on the soil surface, while the other environments were all conventionally tilled, with residues mostly buried.

The experiment had a split-plot design, with cultivar as main plot and fungicide as subplot. Cultivars and fungicides were randomly assigned to main plots and subplots, respectively. Cultivars for the experiment were chosen from among regionally adapted lines with varying levels of scab resistance and varying maturities but similar yield potentials (Table 2). There were four cultivars rated as MR and three cultivars rated as $\mathrm{S}$ to scab. The same seven cultivars were planted in each environment, and the number of replicates within each environment was four.

Equal numbers of seed were planted per plot. Planting was accomplished with a seven-row research cone planter on the research stations and with a commercial drill in the on-farm tests. Plots were planted on normal dates for each location (Table 1). After end trimming, plot area ranged from 9.3 to $14 \mathrm{~m}^{2}$, depending on the experiment.

Inoculation, misting, and fungicide applications. Field experiments were inoculated 2 to 3 weeks prior to flowering with

TABLE 1. Seven North Carolina environments used in 2010 and 2011 to study profitability of host resistance and fungicides in reducing Fusarium head blight (FHB) losses

\begin{tabular}{|c|c|c|c|c|c|c|c|}
\hline Year & Location & County & Site $^{\mathrm{a}}$ & Tillage $^{\mathrm{b}}$ & GPS coordinates & Planting date ${ }^{c}$ & Harvest date \\
\hline 2010 & Monroe & Union & Farm & No-till & $34.9007,-80.5842$ & 4 Nov & 17 June \\
\hline 2010 & Salisbury & Rowan & Station & Conv & $35.6963,-80.6225$ & 21 Oct & 7 June \\
\hline 2011 & Monroe & Union & Farm & No-till & $35.0886,-80.4578$ & 29 Oct & 15 June \\
\hline 2011 & Salisbury & Rowan & Station & Conv & $35.6963,-80.6225$ & 21 Oct & 7 June \\
\hline 2011 & Pantego & Beaufort & Farm & Conv & $35.6054,-76.6462$ & $10 \mathrm{Nov}$ & 9 June \\
\hline 2011 & Rowland & Robeson & Farm & Conv & $34.5491,-79.2798$ & 27 Oct & 2 June \\
\hline 2011 & Raleigh & Wake & Station & Conv & $35.7347,-78.7014$ & $20 \mathrm{Oct}$ & 2 June \\
\hline
\end{tabular}

${ }^{a}$ Farm or research station.

b Conv = Conventional. In both no-till environments, maize was the previous crop.

c November (Nov) or October (Oct).

TABLE 2. Cultivars used in study of profitability of integrated Fusarium head blight (FHB) management techniques in North Carolina environments of low, medium, and high FHB risk in 2010 and 2011

\begin{tabular}{|c|c|c|c|c|c|c|c|}
\hline \multirow[b]{2}{*}{ Cultivar } & \multirow[b]{2}{*}{ Number ${ }^{c}$} & \multirow[b]{2}{*}{ Maturity (JD) ${ }^{\mathrm{d}}$} & \multicolumn{3}{|c|}{ Previous FHB data ${ }^{a}$} & \multicolumn{2}{|c|}{ Previous performance (means of 3 years) ${ }^{b}$} \\
\hline & & & Index $(\%)$ & DON (ppm) & Rating & Yield (Mg ha $\left.{ }^{-1}\right)$ & Test weight $\left(\mathrm{kg} / \mathrm{m}^{3}\right)$ \\
\hline NC Neuse & 200400303 & 107.0 & 23 & 8 & MR & 3.84 & 768.3 \\
\hline DG Dominion & 200600212 & 103.5 & 30 & 8 & MR & 4.17 & 746.5 \\
\hline Coker 9436 & 200500221 & 105.5 & 29 & 15 & MR & 4.04 & 728.4 \\
\hline SS 5205 & 200900396 & 103.5 & 59 & 17 & MR & 4.18 & 743.9 \\
\hline P26R12 & 200200234 & 106.5 & 68 & 35 & S & 4.27 & 756.8 \\
\hline USG 3592 & 200400110 & 104.5 & 72 & 26 & $\mathrm{~S}$ & 4.15 & 752.9 \\
\hline SS 520 (38158) & PI 619052 & 99.5 & 75 & 24 & $\mathrm{~S}$ & 4.10 & 733.6 \\
\hline
\end{tabular}

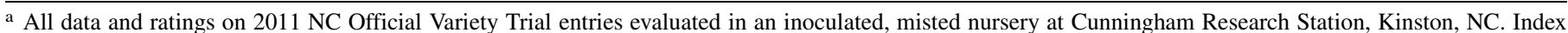
was (incidence $\times$ severity) $/ 100 . \mathrm{DON}=$ deoxynivalenol, $\mathrm{MR}=$ moderately resistant, and $\mathrm{S}=$ susceptible.

b NCOVT data, 2008 to 2010 3-year statewide means.

c PI or Plant Variety Protection (PVP) number.

d Mean of two replicates in Julian days (JD), 2008 NCOVT, Cunningham Research Station. 
Fusarium-infected corn spawn at a rate of $43 \mathrm{~g} \mathrm{~m}^{-2}$. Irrigation was applied in three environments on two, four, or six occasions with aluminum irrigation pipe and sprinklers in half-hour or 1-h sessions (Table 3).

There were three fungicide treatments: Prosaro, Caramba, and an unsprayed control. Fungicides were applied at early flowering (Table 3). Prosaro was applied with a backpack sprayer (Raleigh) or tractor and spray rig (other locations) at a rate ranging from 475 to $585 \mathrm{ml} \mathrm{ha}^{-1}$, and Caramba at a rate of 950 to $1,242 \mathrm{ml} \mathrm{ha}^{-1}$, depending on environment. The flow rate was 178 liter ha ${ }^{-1}, 1.38$ bar, with surfactant at $0.625 \mathrm{ml} / \mathrm{liter}$ of solution.

Assays of symptoms, yield, TW, and damage. The same assessor evaluated disease incidence and severity, on a whole-plot basis, in all plots in all environments. Disease incidence was evaluated as the percentage of spikes with FHB symptoms, and disease severity as the average percentage of blighted spikelets on symptomatic spikes. Disease index was calculated as the product of incidence and severity divided by 100 .

Plots were harvested with research combines (Wintersteiger, Salt Lake City, UT). Grain weight, moisture content, and TW were determined either in-combine or using a grain analysis computer (Dickey-John, Springfield, IL), and yields were computed after adjusting weights to a standard moisture content.

To determine the percentage of FDK, 100 kernels were chosen at random from the harvested grain from each plot and visually inspected for gray-white or pink discoloration and mycelial growth. Grain was assayed for DON content by Dr. Yanhong Dong at the University of Minnesota using gas chromatography-mass spectrometry.

The percentage of infected kernels (PIK) was determined by surface-sterilizing 100 randomly chosen kernels per sample for 2 min in 5\% bleach, and plating them on Komada's selective medium (Komada 1976). Seed were incubated for 7 days in a growth chamber at $22^{\circ} \mathrm{C}$ on a cycle of $12 \mathrm{~h}$ of light and $12 \mathrm{~h}$ of darkness. Infected seed were identified from fluffy peach-white mycelial growth and characteristic discoloration of the medium beneath the seed.

Fungicide application costs. Estimation of fungicide application costs and grain price ranges followed Weisz et al. (2011), with the general approach being to estimate costs and prices that would cover the situation of most wheat producers. The three costs pertaining to a fungicide application specifically to reduce scab were chemicals, application costs, and "drive-down" of wheat. Fungicide applications to reduce FHB occur at flowering, a growth stage at which wheat does not recover from flattening by equipment tires, leading to drive-down costs due to lost yield. On a per-hectare basis in 2010 and 2011, local costs for chemicals were $\$ 35\left(475 \mathrm{ml} \mathrm{ha}^{-1}\right)$ to $\$ 43$ $\left(585 \mathrm{ml} \mathrm{ha}^{-1}\right)$ for Prosaro, and about $\$ 37\left(987 \mathrm{ml} \mathrm{ha}^{-1}\right)$ for Caramba. We chose a representative fungicide cost of $\$ 37.06 \mathrm{ha}^{-1}\left(\$ 15 \mathrm{acre}^{-1}\right)$ in our estimates of partial profit. Commercial ground application costs for a 27.4-m ground sprayer were estimated, via a survey of county extension agents, to be approximately $\$ 17.29 \mathrm{ha}^{-1}$. We used the previously estimated yield loss associated with drive-down of $0.15 \mathrm{Mg}$ $\mathrm{ha}^{-1}$ for a 27.4-m ground sprayer (Weisz et al. 2011) in our calculations.

Grain prices. The factors affecting grain prices were cyclical fluctuations in the SRWW price, whether grain was sold for flour or animal feed, whether wheat was additionally discounted for DON, and discounts for low TW. The price for SRWW in North Carolina ranged over a 10-year period (2004 to 2013) from a low of $\$ 3.07$ $\mathrm{bu}^{-1}\left(\$ 112.80 \mathrm{Mg}^{-1}\right)$ in 2005 to a high of $\$ 7.27 \mathrm{bu}^{-1}\left(\$ 267.13 \mathrm{Mg}^{-1}\right)$ in 2011 (National Agricultural Statistics Service [NASS] of the U.S. Department of Agriculture). We interviewed 21 grain buyers and five county agents from a geographically broad cross-section of North Carolina for information on the differential between foodand feed-grade wheat prices, as well as DON and TW dockage practices. The interviews indicated that the differential between food- and feed-grade wheat prices ranged between $\$ 36.74$ and $\$ 110.23 \mathrm{Mg}^{-1}$. For estimating profitability, we assumed a base grain price of $\$ 5.00 \mathrm{bu}^{-1}\left(\$ 183.67 \mathrm{Mg}^{-1}\right)$ for feed grain markets and $\$ 6.25 \mathrm{bu}^{-1}\left(\$ 229.58 \mathrm{Mg}^{-1}\right)$ for grain destined for flour production. To test the impact of higher grain prices, we also ran our analyses using $\$ 10.00 \mathrm{bu}^{-1}\left(\$ 367.33 \mathrm{Mg}^{-1}\right)$ for feed grain markets and $\$ 11.25 \mathrm{bu}^{-1}\left(\$ 413.25 \mathrm{Mg}^{-1}\right)$ for flour markets.

Market types, dockage, and partial profit. In the interviews with grain buyers, responses varied widely; however, three main types of buyers were identified. These types ranged from least to most stringent with respect to DON testing and dockage and TW dockage (Table 4). The most permissive type was a large buyer of wheat strictly for swine feed. This buyer (referred to from here on as the "feed-grain market") had no dockage for DON, and a modest TW dockage schedule that was well modeled $\left(R^{2}=0.99\right)$ as $Y_{\text {feed }}=$ $0.0000983 X^{2}-0.171 X+71.42$ (equation 1), where $X$ was the TW $\left(\mathrm{kg} \mathrm{m}^{3}\right)$ and $Y_{\text {feed }}$ was the reduction in grain price $\left(\$ \mathrm{Mg}^{-1}\right)$ for TW between 514.8 and $695.0 \mathrm{~kg} \mathrm{~m}^{3}$. For TW at or above $695.0 \mathrm{~kg} \mathrm{~m}^{3}$, there was no dockage. For TW at or below $514.8 \mathrm{~kg} \mathrm{~m}^{3}$, grain was rejected.

TABLE 3. Fungicide application dates, forecasted risk levels, irrigation, and post-anthesis precipitation at seven North Carolina environments used in 2010 and 2011 to study profitability of integrated management of Fusarium head blight (FHB)

\begin{tabular}{|c|c|c|c|c|c|c|}
\hline Year and location & Irrigation & $\begin{array}{c}\text { Distance to } \\
\text { weather station }(\mathrm{km})\end{array}$ & $\begin{array}{c}\text { Post-anthesis } \\
\text { precipitation }(\mathrm{cm})^{\mathrm{a}}\end{array}$ & Spray date & FHB risk forecast ${ }^{b}$ & Cultivar \\
\hline 2010 Monroe & No & 10.4 & 10.8 & 4 May & Low & All \\
\hline \multirow[t]{4}{*}{2010 Salisbury } & $\mathrm{Yes}^{\mathrm{c}}$ & 0.0 & 18.2 & 27 April & Low & SS520 \\
\hline & & & & 30 April & Low & SS5205, USG 3592 \\
\hline & & & & 4 May & Low & C9436, DG Dominion, NC Neuse \\
\hline & & & & 4 May & Medium & $\mathrm{P} 26 \mathrm{R} 12$ \\
\hline \multirow[t]{2}{*}{2011 Monroe } & No & 13.5 & 15.6 & 27 April & Low & All except P26R12 \\
\hline & & & & 29 April & Low & P26R12 \\
\hline 2011 Salisbury & Yes $^{d}$ & 0.0 & 4.0 & 25 April & Low & All \\
\hline \multirow[t]{4}{*}{2011 Pantego } & No & 6.6 & 1.2 & 20 April & Medium & SS5205 \\
\hline & & & & 20 April & High & SS520 \\
\hline & & & & 25 April & Medium & C9436, DG Dominion \\
\hline & & & & 25 April & High & NC Neuse, P26R12, USG 3592 \\
\hline \multirow[t]{3}{*}{2011 Rowland } & No & 21.3 & 4.3 & 15 April & Low & SS520, USG3592 \\
\hline & & & & 19 April & Low & C9436, DG Dominion, SS5205 \\
\hline & & & & 22 April & Low & NC Neuse, P26R12 \\
\hline \multirow[t]{3}{*}{2011 Raleigh } & Yese & 2.1 & 5.4 & 21 April & Low & SS520, SS5205, USG3592 \\
\hline & & & & 26 April & Low & C9436, DG Dominion, NC Neuse \\
\hline & & & & 26 April & Medium & $\mathrm{P} 26 \mathrm{R} 12$ \\
\hline
\end{tabular}

a Total precipitation for the 21-day period starting at the final fungicide application.

b Risk forecast using model of Pennsylvania State University forecasting system (www.wheatscab.psu.edu); details in text.

c Irrigation $=0.64 \mathrm{~cm}$ each on 29 April and 1, 5, and 10 May. Assumption: additional $24 \mathrm{~h}$ of conducive relative humidity (RH)

d Irrigation $=0.64 \mathrm{~cm}$ each on 18, 21, 26, and 28 April and 6 May. Assumption: additional $24 \mathrm{~h}$ of conducive RH.

e Irrigation $=1.3 \mathrm{~cm}$ each on 14 and 20 April. Assumption: additional $48 \mathrm{~h}$ of conducive RH. 
The most stringent buyer was a large flour mill serving bakers selling products for human consumption. For this grain buyer (referred to from here on as the "flour market"), TW $<707.9 \mathrm{~kg} \mathrm{~m}^{3}$ or DON $\geq 2 \mu \mathrm{g} \mathrm{g}^{-1}$ were grounds for rejection. For grain with DON $<2 \mu \mathrm{g} \mathrm{g}^{-1}$, there was no dockage for DON, and TW dockage was well modeled $\left(R^{2}=0.99\right)$ as $Y_{\text {flour }}=0.00319 X^{2}-4.896 X+$ $1,873.04$ (equation 2), where $X$ was the TW $\left(\mathrm{kg} \mathrm{m}^{3}\right)$ and $Y_{\text {flour }}$ was the reduction in grain price $\left(\$ \mathrm{Mg}^{-1}\right)$ for $\mathrm{TW}$ between 707.9 and $746.5 \mathrm{~kg} \mathrm{~m}^{3}$. For TW at or above $746.5 \mathrm{~kg} \mathrm{~m}^{3}$, there was no dockage.

The third grain buyer had a large capacity for blending grain from multiple sources and, consequently, could sell grain to the flour or feed markets (referred to from here on as the "flexible market"), depending on where the greatest profit could be made. This buyer used a sliding scale for DON dockage, such that price was reduced by $\$ 3.67 \mathrm{Mg}^{-1}$ when $2.1 \leq \mathrm{DON} \leq 3 \mu \mathrm{g} \mathrm{g}^{-1}$. Price was reduced by $\$ 9.18 \mathrm{Mg}^{-1}$ when $3.1 \leq \mathrm{DON} \leq 4 \mu \mathrm{g} \mathrm{g}^{-1}$, and grain was rejected when DON exceeded $4 \mu \mathrm{g} \mathrm{g}^{-1}$. TW dockage was well modeled $\left(R^{2}=\right.$ 0.99 ) as $Y_{\text {flex }}=0.00199 X^{2}-3.131 X+1,224.26$ (equation 3), where $X$ was the TW $\left(\mathrm{kg} \mathrm{m}^{3}\right)$ and $Y_{\text {flex }}$ was the reduction in grain price $\left(\$ \mathrm{Mg}^{-1}\right)$ for TW between 669.2 and $746.5 \mathrm{~kg} \mathrm{~m}^{3}$. For TW at or above $746.5 \mathrm{~kg} \mathrm{~m}^{3}$, there was no dockage. For TW at or below $669.2 \mathrm{~kg} \mathrm{~m}^{3}$, grain was rejected.

Partial profit $\left(\$ \mathrm{ha}^{-1}\right)$ for each of the three market types was computed for each subplot. For the untreated plots, partial profit was assumed to equal gross profit (i.e., the product of plot yield multiplied by the grain price minus dockage). If the grain was rejected due to low TW or high DON, the gross profit was assumed to be zero. For the fungicide-treated plots, gross profit was computed as above, but with plot yield lowered by $0.15 \mathrm{Mg} \mathrm{ha}^{-1}$ due to losses resulting from driving over the crop. Partial profit for the fungicidetreated plots was then computed by subtracting both the cost of the fungicide $\left(\$ 37.06 \mathrm{ha}^{-1}\right)$ and the application cost $\left(\$ 17.29 \mathrm{ha}^{-1}\right)$ from the gross profit.

Statistical analyses. The data were analyzed in two ways to examine profitability.

Analysis of cultivar resistance and fungicide treatment on yield, $T W, D O N$, and profit. Perhaps the most striking factor that separated the feed-grain, flour, and flexible markets was their response to grain DON. Consistent with that, our first analytical approach was to assess yield, TW, DON, and profitability of cultivar resistance and fungicide by level of actual epidemic severity (i.e., DON). For this approach, we classified each environment as low-, medium-, or high-DON based on mean levels of $\mathrm{DON}<2 \mu \mathrm{gg}^{-1}, 2 \leq \mathrm{DON}<4 \mu \mathrm{gg}^{-1}$, and DON $\geq 4 \mu \mathrm{g} \mathrm{g}^{-1}$, respectively. Agronomic responses were analyzed using the MIXED procedure in SAS (Littell et al. 2006) (Supplementary File S1). Fixed-effect factors were environment, rating (i.e., resistance to FHB), cultivars, fungicide, and their interactions. Random effects were replicate within environment, and replicate-cultivar within environment and rating. Pairwise $t$ tests to compare adjusted means were carried out and the macro pdmix (Saxton 1998) at $\alpha=0.05$ was used to generate groups of homogenous predicted means. The analysis was run separately for each DON category. The responses of MR and S cultivars in terms of yield, TW, and DON within each category of environment were then determined.

For the analysis of profitability, the three fungicide treatments were simplified to two (treated or untreated) by averaging the response variables for the two fungicides within each main plot. The linear mixed model included the variables of environment, rating, cultivars within rating, fungicide (treated or untreated), and the interactions of those variables as fixed effects. The random effects were replicate within environment and replicate-cultivar within environment and rating. A pairwise $t$ test to compare adjusted means was carried out, and the macro $p d m i x$ (Saxton, 1998) at $\alpha=0.05$ was used to generate groups of homogenous predicted means. The analysis was run separately for each DON environment category and each market type.
Risk assessment tool. Our second objective was to determine how the real-time use of the FHB Prediction Center (www. wheatscab.psu.edu) risk assessment tool in fungicide decisions would have influenced profitability as determined by yield, TW, and DON. Data were divided into two categories (i.e., "do spray" or "do not spray") based on forecasted risk. That is, it was assumed that a grower would spray at flowering if the predicted risk of an epidemic of $>10 \%$ field severity (index) was medium or high. If the risk at flowering was low, it was assumed the grower would not spray.

FHB risk forecasts were calculated according to the equation for winter wheat that was used starting in 2015 by the FHB Prediction Center at Pennsylvania State University (PSU). It should be noted that these forecasts are for epidemics of $>10 \%$ index, and are not DON forecasts. The model allows the user to specify cultivar resistance level. For $\mathrm{S}$ winter wheat cultivars, the risk probability was calculated as $P=e^{\mathrm{x}} /\left(1+e^{\mathrm{x}}\right)$ (equation 4), where $x=-10.2050035-$ $0.9006677+0.1392848 \times \mathrm{RH} \_14$, with $\mathrm{RH} \_14$ being $\mathrm{RH}$ averaged first over each $24-\mathrm{h}$ period and then over the 14 days prior to the flowering date (S. Crawford, PSU, personal communication). The only difference for MR cultivars was that -0.9006677 was replaced with -1.6681503 .

For each cultivar-environment combination, $P$ was calculated as a decimal value and characterized as low $(P<0.20)$, medium $(0.20<P<0.40)$, or high $(0.40<P<1.0)$ risk. The closest weather stations with complete datasets were used for RH data (Table 3). To account for irrigation in estimating risk, it was assumed that, in the Salisbury environments, RH was $100 \%$ for $1 \mathrm{~h}$, then $95 \%$ for the following $23 \mathrm{~h}$. At Raleigh, it was assumed that $\mathrm{RH}$ was $100 \%$ for $1 \mathrm{~h}$, then $95 \%$ for the following $47 \mathrm{~h}$.

We sought to use the risk forecast to predict the profitability of fungicide application. For this analysis, the data were considered as 49 environment-cultivar combinations, each of which was assigned either a "do spray" or "do not spray" recommendation, as described above. These recommendations were based on the risk forecast for that

TABLE 4. Three test weight discount schedules $\left(\$ \mathrm{Mg}^{-1}\right)$ representing the range of market conditions for wheat in North Carolina and used in the present study for partial profit analyses

\begin{tabular}{|c|c|c|c|}
\hline $\begin{array}{l}\text { Test weight } \\
\left(\mathrm{kg} \mathrm{m}^{3}\right)^{\mathrm{a}}\end{array}$ & $\begin{array}{l}\text { Least stringent } \\
\text { (feed only) }^{\mathrm{b}}\end{array}$ & $\begin{array}{c}\text { Intermediate } \\
\text { stringency } \\
\text { (flour or feed) }^{\mathrm{c}}\end{array}$ & $\begin{array}{l}\text { Most stringent } \\
\text { (flour only) }^{\mathrm{d}}\end{array}$ \\
\hline Above 746 & No discount & No discount & No discount \\
\hline $745-740$ & No discount & $-\$ 0.73$ & $-\$ 1.10$ \\
\hline $739-734$ & No discount & $-\$ 1.47$ & $-\$ 2.20$ \\
\hline $732-727$ & No discount & $-\$ 2.57$ & $-\$ 3.67$ \\
\hline $726-721$ & No discount & $-\$ 4.41$ & $-\$ 5.14$ \\
\hline $719-714$ & No discount & $-\$ 6.24$ & $-\$ 7.35$ \\
\hline $713-708$ & No discount & $-\$ 8.08$ & $-\$ 9.55$ \\
\hline 707-701 & No discount & $-\$ 9.92$ & Reject \\
\hline $700-695$ & No discount & $-\$ 11.75$ & Reject \\
\hline 694-689 & $-\$ 0.37$ & $-\$ 14.32$ & Reject \\
\hline $687-682$ & $-\$ 0.37$ & $-\$ 16.90$ & Reject \\
\hline $674-669$ & $-\$ 0.73$ & $-\$ 22.04$ & Reject \\
\hline $668-656$ & $-\$ 1.10$ & Reject & Reject \\
\hline $655-644$ & $-\$ 1.47$ & Reject & Reject \\
\hline $642-515$ & $-\$ 2.20$ & Reject & Reject \\
\hline $629-618$ & $-\$ 2.94$ & Reject & Reject \\
\hline $616-605$ & $-\$ 3.67$ & Reject & Reject \\
\hline $604-592$ & $-\$ 4.41$ & Reject & Reject \\
\hline $591-579$ & $-\$ 5.14$ & Reject & Reject \\
\hline $578-566$ & $-\$ 5.88$ & Reject & Reject \\
\hline $565-553$ & $-\$ 6.61$ & Reject & Reject \\
\hline $552-541$ & $-\$ 7.35$ & Reject & Reject \\
\hline $539-528$ & $-\$ 8.08$ & Reject & Reject \\
\hline $526-515$ & $-\$ 8.82$ & Reject & Reject \\
\hline Below 515 & Reject & Reject & Reject \\
\hline
\end{tabular}

a Scale ranges from a high of $58 \mathrm{lb}$. bu $\mathrm{bu}^{-1}$ to a low of $40 \mathrm{lb} \cdot \mathrm{bu}^{-1}$.

b No testing for deoxynivalenol (DON).

c DON policy: dock $\$ 3.67 \mathrm{Mg}^{-1}\left(\$ 0.10 \mathrm{bu}^{-1}\right)$ at 2.1 to $3 \mu \mathrm{g} \mathrm{g}^{-1}$, dock $\$ 9.18$ $\mathrm{Mg}^{-1}\left(\$ 0.25 \mathrm{bu}^{-1}\right)$ at 3.1 to $4 \mu \mathrm{g} \mathrm{g}^{-1}$, and reject at $\geq 4 \mu \mathrm{g} \mathrm{g}^{-1}$.

${ }^{\mathrm{d}}$ DON policy: reject at $\geq 2 \mu \mathrm{g} \mathrm{g}^{-1}$. 
particular cultivar, rated S or MR (Table 2), at flowering at that location. We wished to see how actual index and DON aligned with the level of risk predicted, while recognizing that the risk tool is designed to predict probability of index $>10 \%$, not DON. For each recommendation, and using only the unsprayed control plot data, we determined the mean, range, and standard deviation of actual index and DON levels. Also, for each environment-cultivar combination, the mean economic benefit of spraying was computed as the difference between the partial profit for sprayed plots (with the Caramba and Prosaro treatments averaged together) and the partial profit for unsprayed plots.

\section{RESULTS}

Relationships among FHB damage variables. The three direct measures of FHB damage at harvest-DON, FDK, and PIK-were strongly correlated with each other (Table 5). Thus, least-squares means of DON concentrations were taken to represent all three direct measures of damage at harvest time (Table 6), and the FDK and PIK data are not shown. Additionally, mean DON was used to characterize disease level at each environment (Table 6) as low $\left(\mathrm{DON}<2 \mu \mathrm{g} \mathrm{g}^{-1}\right)$, medium $\left(2 \leq \mathrm{DON}<4 \mu \mathrm{g} \mathrm{g}^{-1}\right)$, or high $(\mathrm{DON} \geq$ $\left.4 \mu \mathrm{g} \mathrm{g}^{-1}\right)$. There were two low-DON environments, four medium-DON environments, and one high-DON environment. Yield was weakly negatively correlated with index, DON, and FDK (Table 5; $-0.29 \leq r \leq-0.19)$ but uncorrelated with PIK $(P=0.51)$. TW was weakly to moderately negatively correlated with all four measures of FHB $(-0.37 \leq r \leq-0.28)$.

Index (Table 7) had a moderate degree of positive correlation $(r=$ 0.47 to 0.49 ) with the three direct measures of damage at harvest (Table 5). Within low-, medium-, and high-DON environments, index was associated with DON but the slope of the relationship differed across environments (Fig. 1). In other words, a given level of disease symptoms was associated with less DON in the low-DON environments, intermediate DON in the medium-DON environments, and more DON in the high-DON environment. There were many cases where the index was $<10$ but DON levels would have resulted in grain being rejected at the buying point (Fig. 1). Likewise, there were cases where index was $\geq 10$ but DON levels remained low. There was no correspondence between average DON within environments (Table 6) and postanthesis rainfall (Table 3).

Yield, TW, and DON effects. Yield. In the low-DON environments, differences in yield between treatments were relatively small (Fig. 2A). On average, fungicide had no impact on yield ( $P=$ $0.10)$ and, within a resistance class, there were no significant yield differences due to fungicide treatment $(P=0.66)$. Even so, the combination of fungicide and cultivar resistance yielded better than

TABLE 5. Coefficients of correlation $(r)$ for the relationships among dependent variables in seven-environment North Carolina study of profitability of techniques for managing Fusarium head blight of wheat ${ }^{\mathrm{a}}$

\begin{tabular}{|c|c|c|c|c|c|c|c|c|}
\hline & Yield & TW & DI & DS & Index & DON & FDK & PIK \\
\hline Yield & 1.0 & NS & $-0.34 * *$ & NS & $-0.29 * *$ & $-0.20 *$ & $-0.19 *$ & NS \\
\hline TW & $\ldots$ & 1.0 & $-0.14 *$ & $-0.25^{* *}$ & $-0.22 * *$ & $-0.28 * *$ & $-0.31 * *$ & $-0.37 * *$ \\
\hline DI & $\ldots$ & $\ldots$ & 1.0 & $0.46^{* *}$ & $0.91^{* *}$ & $0.55^{* *}$ & $0.55^{* *}$ & $0.52 * *$ \\
\hline Index & $\ldots$ & $\ldots$ & $\ldots$ & $\ldots$ & 1.0 & $0.48 * *$ & $0.49 * *$ & $0.47 * *$ \\
\hline DON & $\ldots$ & $\ldots$ & $\ldots$ & $\ldots$ & $\ldots$ & 1.0 & $0.97 * *$ & $0.85^{* *}$ \\
\hline FDK & $\ldots$ & $\ldots$ & $\ldots$ & $\ldots$ & $\ldots$ & $\ldots$ & 1.0 & $0.87 * *$ \\
\hline PIK & $\ldots$ & $\ldots$ & $\ldots$ & $\ldots$ & $\ldots$ & $\ldots$ & $\ldots$ & 1.0 \\
\hline
\end{tabular}

a $\mathrm{TW}=$ test weight, $\mathrm{DI}=$ disease incidence (percentage of spikes blighted), DS = disease severity (mean blighted proportion of affected spikes), DON = deoxynivalenol, FDK $=$ Fusarium-damaged kernels, and PIK $=$ percent $F$ usarium-infected kernels. NS indicates $P>0.05, *$ indicates $0.01<P<0.05$, and ** indicates $P<0.01$.

TABLE 6. Deoxynivalenol (DON) concentrations in study of economics of host resistance and fungicide in North Carolina environments of varying Fusarium head blight (FHB) intensity in 2010 and 2011

\begin{tabular}{|c|c|c|c|c|c|c|c|c|c|}
\hline \multirow[b]{2}{*}{ Cultivar } & \multirow[b]{2}{*}{$\mathrm{FHB}^{\mathrm{b}}$} & \multirow[b]{2}{*}{ Treatment } & \multicolumn{7}{|c|}{ DON $\left(\mu g^{-1}\right)^{a}$} \\
\hline & & & Monroe 2010 & Salisbury 2010 & Monroe 2011 & Salisbury 2011 & Pantego 2011 & Rowland 2011 & Raleigh 2011 \\
\hline \multirow[t]{3}{*}{ NC Neuse } & MR & Untreated & 0.8 & 2.7 & 0.3 & 3.0 & 1.7 & 2.6 & 7.5 \\
\hline & $\ldots$ & Caramba & 0.4 & 1.6 & 0.1 & 2.3 & 1.3 & 2.3 & 2.7 \\
\hline & $\ldots$ & Prosaro & 0.4 & 1.9 & 0.1 & 2.8 & 1.6 & 1.8 & 7.6 \\
\hline \multirow[t]{3}{*}{ DG Dominion } & MR & Untreated & 1.1 & 3.5 & 0.5 & 3.1 & 1.0 & 2.7 & 9.0 \\
\hline & $\ldots$ & Caramba & 0.4 & 1.8 & 0.3 & 1.4 & 0.5 & 1.4 & 4.9 \\
\hline & $\ldots$ & Prosaro & 0.2 & 2.9 & 0.3 & 2.2 & 0.9 & 1.6 & 3.1 \\
\hline \multirow[t]{3}{*}{ Coker 9436} & MR & Untreated & 1.2 & 3.5 & 0.3 & 4.7 & 2.3 & 4.2 & 6.6 \\
\hline & $\ldots$ & Caramba & 0.2 & 2.1 & 0.1 & 5.2 & 1.3 & 4.6 & 3.7 \\
\hline & $\ldots$ & Prosaro & 0.3 & 2.2 & 0.3 & 4.1 & 2.3 & 4.1 & 3.4 \\
\hline \multirow[t]{3}{*}{ SS 5205} & MR & Untreated & 0.7 & 0.9 & 0.6 & 1.7 & 1.2 & 2.1 & 9.1 \\
\hline & $\ldots$ & Caramba & 0.3 & 1.1 & 0.1 & 1.8 & 0.9 & 1.1 & 6.1 \\
\hline & $\ldots$ & Prosaro & 0.3 & 1.8 & 0.2 & 1.9 & 0.7 & 0.9 & 7.4 \\
\hline \multirow[t]{3}{*}{ P26R12 } & $\mathrm{S}$ & Untreated & 2.7 & 5.1 & 0.8 & 4.9 & 2.9 & 7.1 & 15.4 \\
\hline & $\ldots$ & Caramba & 1.1 & 2.2 & 0.3 & 4.3 & 1.3 & 2.9 & 6.8 \\
\hline & $\ldots$ & Prosaro & 0.8 & 3.7 & 0.4 & 3.7 & 2.5 & 3.4 & 11.1 \\
\hline \multirow[t]{3}{*}{ USG 3592} & $S$ & Untreated & 1.3 & 1.5 & 0.5 & 4.1 & 8.1 & 5.6 & 14.1 \\
\hline & $\ldots$ & Caramba & 0.6 & 2.3 & 0.1 & 3.3 & 7.6 & 3.6 & 9.3 \\
\hline & $\ldots$ & Prosaro & 0.6 & 3.2 & 0.4 & 3.7 & 9.7 & 2.9 & 11.6 \\
\hline \multirow[t]{3}{*}{ SS 520} & $\mathrm{~S}$ & Untreated & 1.2 & 2.1 & 0.4 & 2.7 & 3.4 & 2.4 & 6.3 \\
\hline & $\ldots$ & Caramba & 0.3 & 2.3 & 0.1 & 1.9 & 1.4 & 1.9 & 5.5 \\
\hline & $\ldots$ & Prosaro & 0.5 & 1.7 & 0.2 & 2.2 & 1.5 & 1.7 & 4.6 \\
\hline Mean & $\ldots$ & $\ldots$ & 0.7 & 2.1 & 0.3 & 3.1 & 2.6 & 2.9 & 7.4 \\
\hline DON env ${ }^{c}$ & $\ldots$ & $\ldots$ & Low & Medium & Low & Medium & Medium & Medium & High \\
\hline
\end{tabular}

a Values are least square means of four replicate plots.

b Rating: $M R=$ moderately resistant and $\mathrm{S}=$ susceptible.

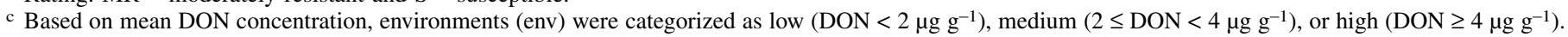


the absence of both. Averaged across fungicide treatments, MR cultivars out-yielded $\mathrm{S}$ ones $(P=0.04)$. In medium-DON environments, sprayed treatments yielded significantly better than unsprayed treatments within both resistance classes but variety resistance (in the absence of fungicide) did not out-yield susceptibility. In the high-DON environment, MR cultivars out-yielded $\mathrm{S}$ ones $(P<0.0001)$, fungicides outyielded unsprayed treatments $(P<0.0001)$, and Caramba outyielded Prosaro. Overall, as expected, adding disease pressure tended to increase the yield benefits of both variety resistance and fungicides.

$T W$. In low-DON environments, there were no significant differences in TW (Fig. 2B). In both the medium- and high-DON environments, Caramba resulted in a higher TW than not spraying. In the medium-DON environments, there was no significant difference between $\mathrm{MR}$ and $\mathrm{S}$ varieties $(P=0.81)$. In the high-DON environment, MR varieties had higher TW than $\mathrm{S}$ varieties $(P=0.01)$. In general,

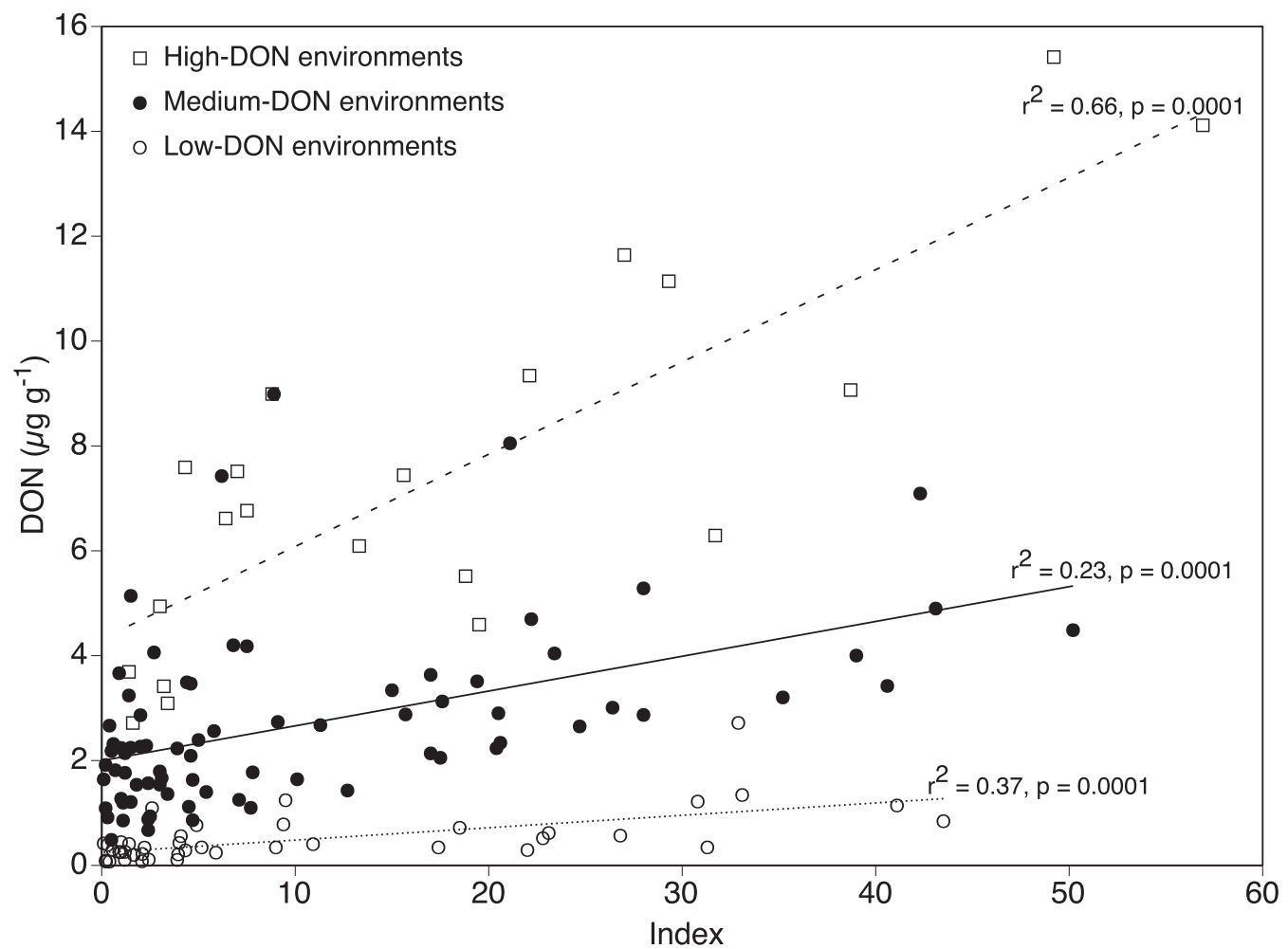

Fig. 1. Deoxynivalenol (DON) plotted against index ([incidence $\times$ severity $] / 100)$ for one high-DON $\left(\geq 4 \mu \mathrm{g} \mathrm{g}^{-1}\right)$, four medium-DON $\left(2 \leq \mathrm{DON}<4 \mu \mathrm{gg} \mathrm{g}^{-1}\right)$, and two low-DON $\left(<2 \mu \mathrm{g} \mathrm{g}^{-1}\right)$ environments in a North Carolina experiment on profitability of integrated Fusarium head blight management.

TABLE 7. Fusarium head blight (FHB) index in study of economics of host resistance and fungicide in North Carolina environments of varying FHB intensity in 2010 and 2011

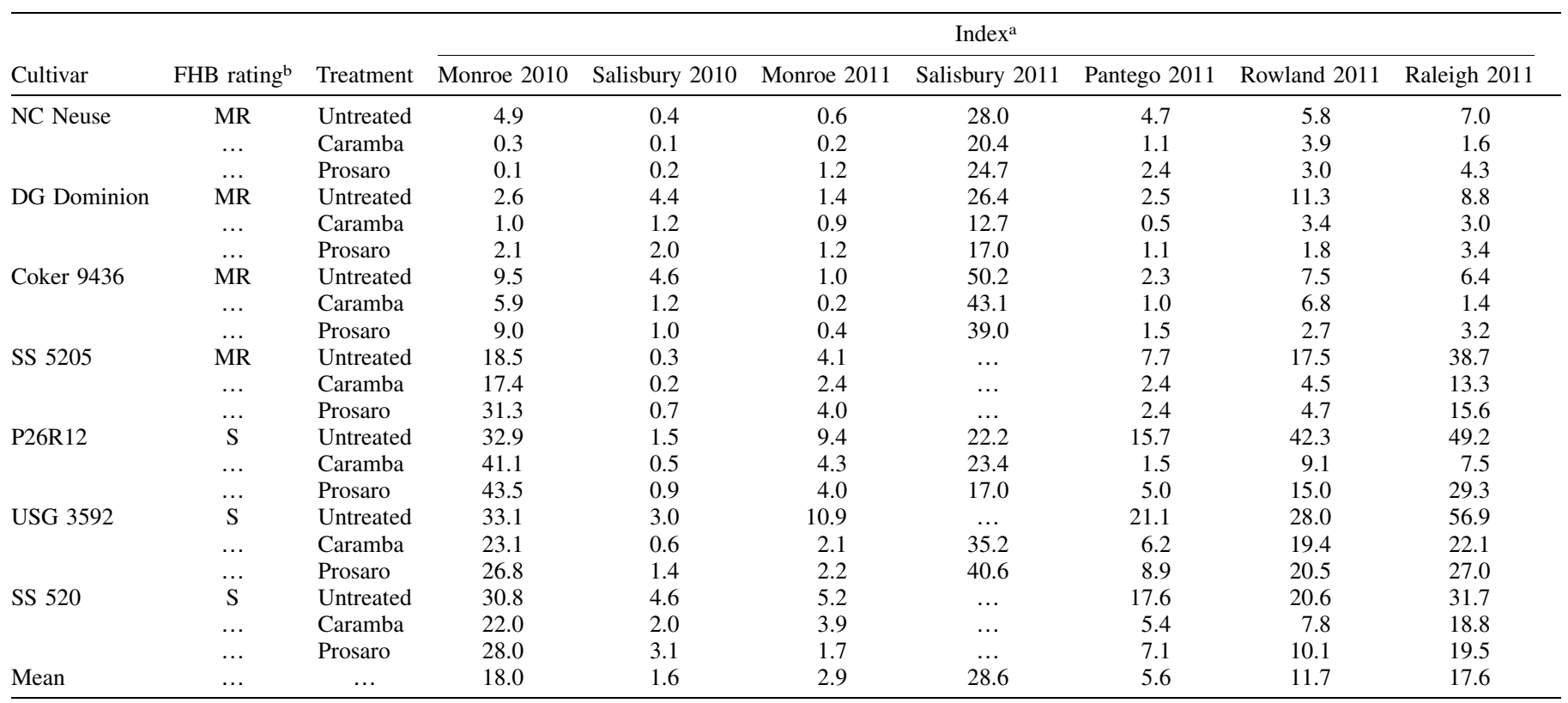

a Values are least square means of four replicate plots.

${ }^{\mathrm{b}} \mathrm{MR}=$ moderately resistant and $\mathrm{S}=$ susceptible. 
treatments had less impact on TW than on yield or DON in the context of the range of disease levels available in this study. TW was affected by environmental factors other than FHB, with higher mean TW in the medium-DON environments than in either low- or high-DON environments (Fig. 2B).

$D O N$. Across environments, mean DON levels ranged from $<1 \mu \mathrm{g}$ $\mathrm{g}^{-1}$ to $>11 \mu \mathrm{g} \mathrm{g}^{-1}$ (Fig. 2C). Even in the low-DON environments, both fungicides and variety resistance reduced DON significantly $(P<$ 0.0001 in both cases). In medium-DON environments, fungicides reduced DON significantly $(P<0.0001)$ relative to unsprayed treatments, and MR varieties had significantly less DON than $S$ ones $(P<0.0001)$. Treatment differences were pronounced in the
high-DON environment, with both resistance and fungicides having significant DON-reducing impact $(P<0.0001$ in both cases), and a trend for Caramba to reduce DON more than Prosaro. In all three types of environment, the combination of variety resistance and fungicide had the greatest DON-reducing effect.

Effects of FHB damage on partial profit. Using the economic assumptions described above and the yield, TW, and DON values for each plot, the three basic profitability scenarios were modeled (Fig. 3). Increasing grain price from $\$ 183.67 \mathrm{Mg}^{-1}$ to $\$ 367.33 \mathrm{Mg}^{-1}$ for the feed grain market, or from $\$ 229.58 \mathrm{Mg}^{-1}$ to $\$ 413.25 \mathrm{Mg}^{-1}$ for the flexible or flour-only markets, increased overall profit as expected; however, the rank and statistical separation of

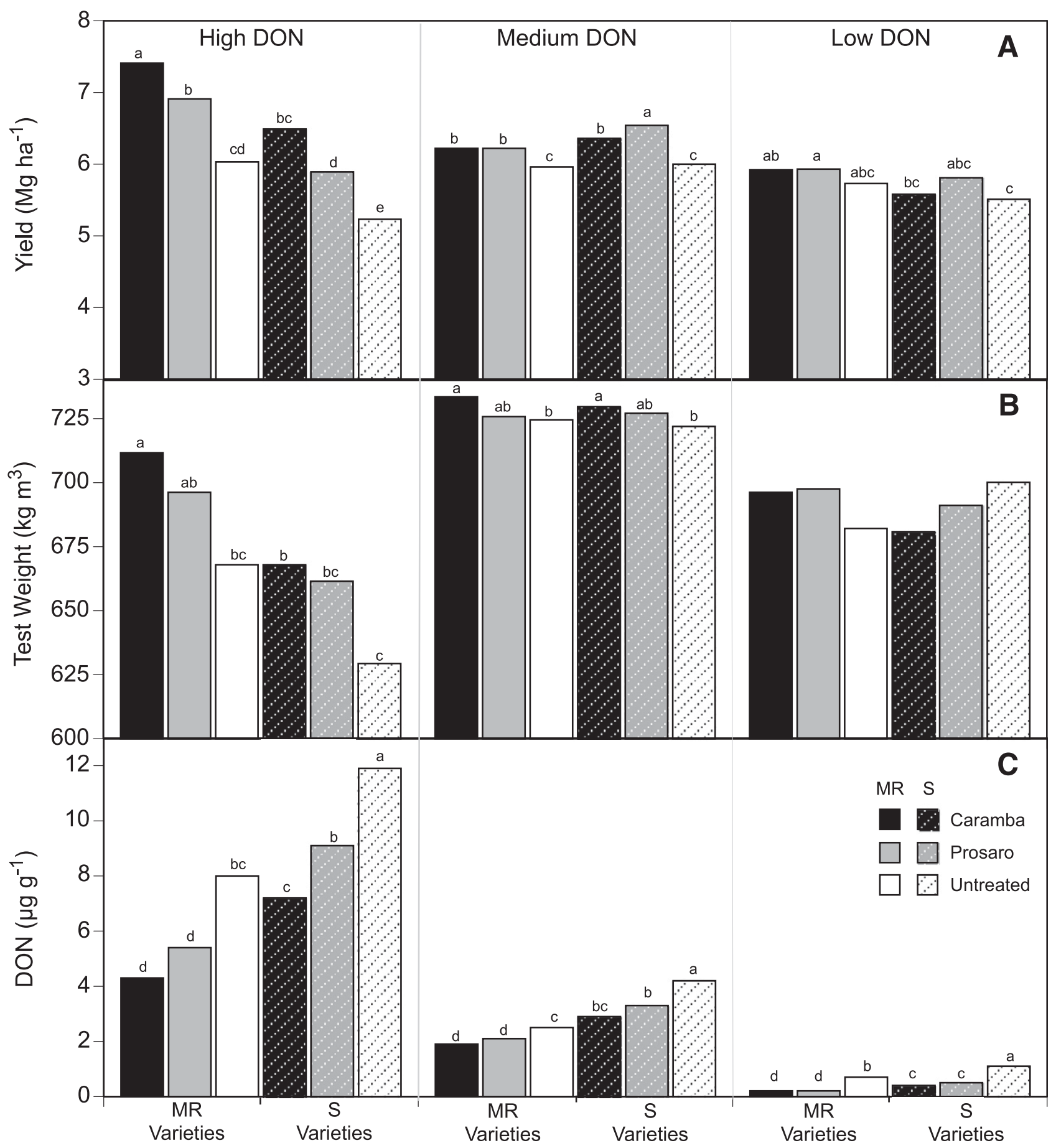

Fig. 2. Profit determinants as affected by wheat scab epidemics in four moderately resistant (MR) and three susceptible (S) varieties sprayed with Caramba or Prosaro or untreated in seven North Carolina environments in 2010 and 2011 , analyzed separately in one high-deoxynivalenol (DON) ( $\left.\geq 4 \mu \mathrm{g} \mathrm{g}^{-1}\right)$, four mediumDON $\left(2 \leq\right.$ DON $\left.<4 \mu \mathrm{g} \mathrm{g}^{-1}\right)$, and two low-DON $\left(<2 \mu \mathrm{g} \mathrm{g}^{-1}\right)$ environments: A, yield; B, test weight; and $\mathbf{C}$, DON. Within DON environments, treatment means associated with different letters are significantly different at the $5 \%$ level. 
treatment means remained unchanged (data not shown). Consequently, only partial profit results using the more realistic grain prices of $\$ 183.67 \mathrm{Mg}^{-1}$ for feed wheat and $\$ 229.58 \mathrm{Mg}^{-1}$ for the flexible and flour markets are shown.

Overall, partial profits were highest in the feed-grain market even though the grain price offered prior to dockage was $\$ 45.92 \mathrm{Mg}^{-1}$, lower than for the other two purchasers (Fig. 3). Additionally, the feed-grain market was the only one in which wheat production was profitable when DON was high. On average, profits were lowest in the flour market (Fig. 3C), which had the most stringent dockage for both DON and TW.

In the feed-grain market (Fig. 3A), when DON was low or medium, a fungicide was not more profitable than not spraying. In fact, with medium DON, it was slightly less profitable to spray an MR cultivar than not to spray it. When DON was high, both MR cultivars and fungicides significantly increased profits, and the highest partial profit resulted from combining the two techniques. Overall, MR cultivars were at least as profitable as $\mathrm{S}$ cultivars in this market regardless of FHB severity.

In the flexible feed and flour market (Fig. 3B), when DON was low, fungicides were not significantly more profitable than not spraying; in fact, spraying $\mathrm{S}$ cultivars was less profitable than not spraying them. When DON was medium, fungicides were significantly more profitable with $\mathrm{S}$ cultivars but not with MR cultivars. When DON was high, it was only possible to make a profit by spraying MR cultivars; $S$ cultivars were unprofitable with or without fungicide, as were unsprayed MR cultivars. Overall, MR cultivars were also at least as profitable as $\mathrm{S}$ cultivars in the flexible market, regardless of FHB severity.

In the flour market (Fig. 3C), when DON was low, fungicides were not significantly more profitable than not spraying. With medium DON, the combination of MR cultivars and fungicides was significantly more profitable than either resistance or fungicide as individual techniques; S cultivars were low-profit, whether sprayed or unsprayed. With high DON, wheat could not be sold in this market at a profit (i.e., all grain was rejected), regardless of resistance level or fungicide; consequently, applying a fungicide resulted in a net loss. Overall, profits were lower in the flour market than in the other markets, and MR cultivars were again at least as profitable as $\mathrm{S}$ cultivars, regardless of FHB severity.

Profitability and the risk assessment tool. The model predicted medium or high risk of $>10 \%$ index (interpreted as "do spray") for 10 environment-cultivar combinations, of which 4 actually had index $>10 \%$ (Table 8 ). MR and S cultivars both received "do spray" and "do not spray" recommendations (data not shown). Of the 36 combinations forecasted to have low risk

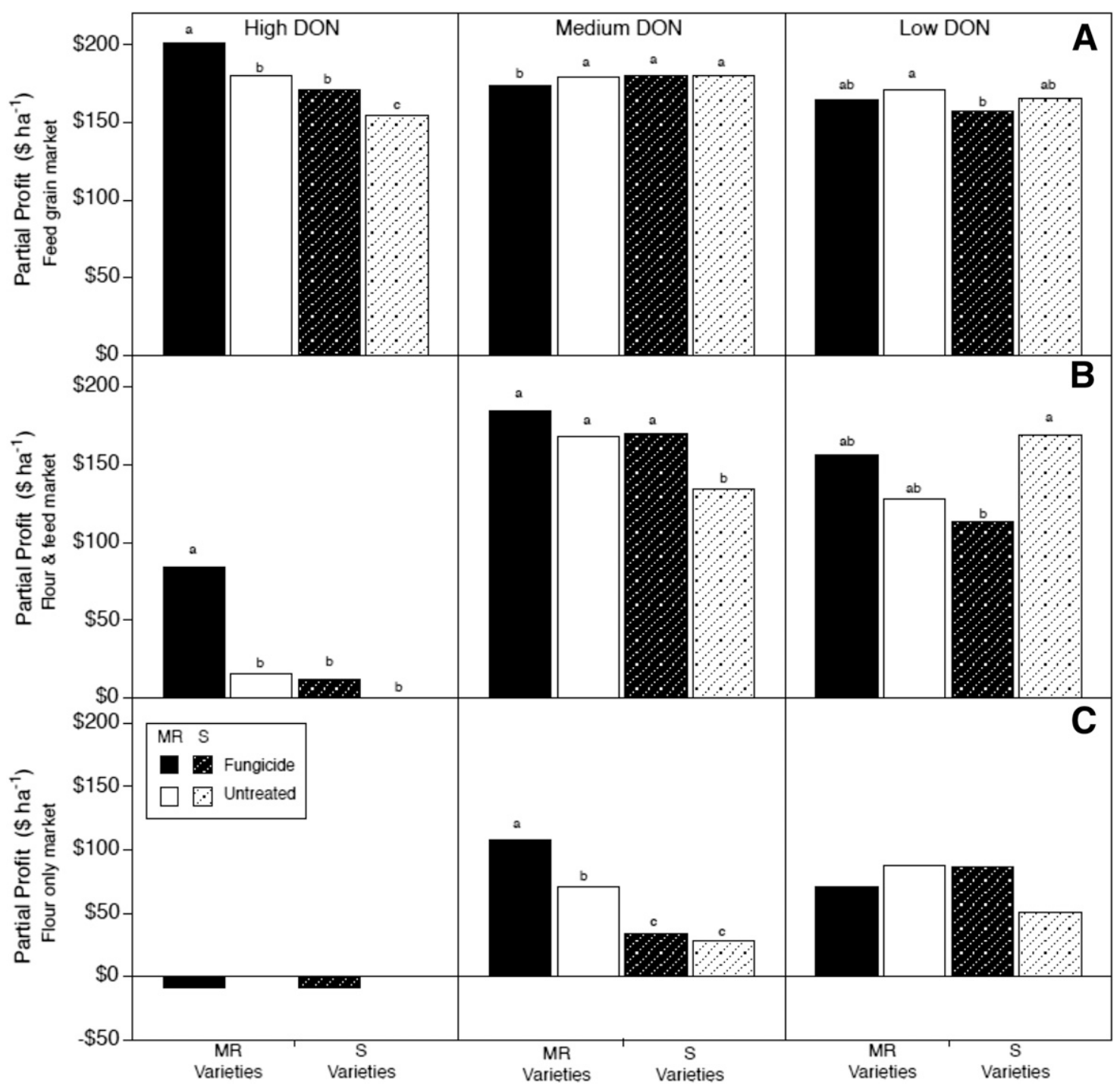

Fig. 3. Profitability as affected by wheat scab epidemics with four moderately resistant (MR) and three susceptible (S) varieties treated or untreated with a fungicide in seven North Carolina environments in 2010 and 2011, analyzed separately in one high-deoxynivalenol (DON) $\left(\geq 4 \mu \mathrm{g} \mathrm{g} \mathrm{g}^{-1}\right)$, four medium-DON $(2 \leq$ DON $\left.<4 \mu \mathrm{g} \mathrm{g}^{-1}\right)$, and two low-DON $\left(<2 \mu \mathrm{g} \mathrm{g}^{-1}\right)$ environments in A, feed-grain market; B, flexible market (flour or feed grain); and $\mathbf{C}$, flour market. Within DON environments, treatments means associated with different letters are significantly different at the $5 \%$ level. 
(interpreted as "do not spray"), 53\% had index $\leq 10 \%$ (Table 8). Thus, as measured by the ability to correctly assign cases above and below the $10 \%$ index ceiling, the sensitivity of the model (ability to correctly predict a positive) was $40 \%$ and the specificity (ability to correctly predict a negative) was 53\%. Overall accuracy (percentage of cases correctly assigned by our definition) was $50 \%$. Mean index for the "do spray" combinations was $11.1 \%$, whereas it was $16.7 \%$ for the "do not spray" combinations.

For purposes of this analysis, "correct" assignment was also defined as having placed an environment-cultivar combination in the "do spray" category if DON turned out to be $>2 \mu \mathrm{g} \mathrm{g}^{-1}$, and otherwise having placed it in the "do not spray" category (Table 8). Assignments were correct with respect to DON in $43 \%$ of cases overall. Mean DON was above the ceiling $\left(3.2 \mu \mathrm{g} \mathrm{g}^{-1}\right)$ in the "do not spray" category. In addition, "correct assignment" was defined as the partial profit from a fungicide application exceeding $\$ 0 \mathrm{ha}^{-1}$ from spraying in the "do spray" category, and being $<\$ 0 \mathrm{ha}^{-1}$ from spraying in the "do not spray" category. Here, assignments were correct in 47 to $65 \%$ of cases overall, depending on the market type (Table 8).

\section{DISCUSSION}

This study highlights the importance of going beyond measures of disease to consider the economics associated with fungicide applications for FHB control. In high- and medium-DON environments, fungicides resulted in increased yield and TW and decreased grain DON. Even in low-DON environments, DON levels decreased and there was a slight trend (not statistically significant) for higher yields following fungicide application. These agronomic results would seem to suggest that fungicide for FHB control should be standard practice, at least under the conditions in our tests.

TABLE 8. Fusarium head blight (FHB) index, deoxynivalenol (DON), and fungicide profitability outcomes from separating 49 cultivar-environment combinations (seven soft red winter wheat cultivars and seven North Carolina environments) by FHB risk forecast into "do spray" and "do not spray" categories at floweringa

\begin{tabular}{lccrrc}
\hline Variable $^{\mathrm{b}}$ & $N$ & Correct $(\%)$ & Mean & \multicolumn{1}{c}{ SD } & Range \\
\hline Overall & & & & & \\
$\quad$ Index & 46 & 52 & 15.5 & 15.1 & $0.3-56.9$ \\
DON & 49 & 45 & 3.4 & 3.3 & $0.2-15.4$ \\
$\quad$ Profitability & & & & & \\
$\quad$ Feed & 49 & 55 & $-\$ 3.55$ & $\$ 35.42$ & $-\$ 56.58-93.13$ \\
$\quad$ Flexible & 49 & 49 & $\$ 45.26$ & $\$ 162.35$ & $-\$ 351.98-559.44$ \\
$\quad$ Flour & 49 & 67 & $\$ 34.73$ & $\$ 189.31$ & $-\$ 426.48-489.49$ \\
"Do spray" & & & & & \\
$\quad$ Index & 9 & 44 & 12.0 & 10.2 & $2.3-31.7$ \\
DON & 9 & 67 & 4.5 & 4.7 & $0.9-15.4$ \\
Profitability & & & & & \\
$\quad$ Feed & 9 & 33 & $\$ 2.02$ & $\$ 29.17$ & $-\$ 37.44-56.98$ \\
$\quad$ Flexible & 9 & 67 & $\$ 71.90$ & $\$ 139.60$ & $-\$ 35.14-396.40$ \\
$\quad$ Flour & 9 & 56 & $\$ 93.01$ & $\$ 160.98$ & $-\$ 22.00-465.42$ \\
"Do not spray" & & & & & \\
Index & 37 & 54 & 16.4 & 16.1 & $0.3-56.9$ \\
$\quad$ DON & 40 & 40 & 3.2 & 3.0 & $0.2-14.1$ \\
Profitability & & & & & \\
$\quad$ Feed & 40 & 60 & $-\$ 4.80$ & $\$ 36.89$ & $-\$ 56.58-93.13$ \\
$\quad$ Flexible & 40 & 45 & $\$ 39.27$ & $\$ 168.05$ & $-\$ 351.98-559.44$ \\
$\quad$ Flour & 40 & 70 & $\$ 21.62$ & $\$ 194.50$ & $-\$ 426.48-489.49$ \\
\hline
\end{tabular}

a "Do spray" = medium or high risk by the FHB risk model (www.wheatscab. psu.edu) and "do not spray" = low risk. Mean, standard deviation (SD), and range are in percentage for index, $\mu \mathrm{g} \mathrm{g}^{-1}$ for DON, and $\$ \mathrm{ha}^{-1}$ for profitability. Correct defined here as $>10 \%$ index, $>2 \mu \mathrm{g} \mathrm{g}^{-1}$ DON, and $>\$ 0 \mathrm{ha}^{-1}$ fungicide profitability for "Do spray" and as $\leq 10 \%$ index, DON $<2 \mu \mathrm{g} \mathrm{g}^{-1}$, and fungicide profitability $<\$ 0 \mathrm{ha}^{-1}$ for "Do not spray."

b Risk model is designed to predict risk of an FHB epidemic of $>10 \%$ index. Additional variables were included to test whether the risk model could be used to predict profitability of applying a fungicide. Profitability of applying fungicide versus not applying fungicide (mean of plots sprayed with Prosaro or Caramba minus unsprayed control) was estimated for feed-grain, flexible (feed or flour), and flour markets.
Yet, although the agronomic data would support the recommendation always to use a scab-targeted fungicide, the results based on the economic data were more complicated. In the feed-grain market, fungicides were only profitable at one environment, where mean DON was $\geq 4 \mu \mathrm{g} \mathrm{g}^{-1}$ (Fig. 3A). In the flexible feed and flour market, there was a trend (not always statistically significant) for fungicide use on MR varieties to be more profitable then not spraying. For $\mathrm{S}$ varieties, results in this market were mixed, with fungicide use in low-DON environments leading to an economic loss, in mediumDON environments to an economic gain, and in high-DON environments to little benefit, because most grain was rejected by this buyer (Fig. 3B). For sales to the flour-only buyer, fungicide use was only profitable with medium DON levels and when paired with MR varieties (Fig. 3C). Increasing the grain price to levels higher than observed in the last 10 years did not change these results.

An important conclusion from the economic results is that, in FHB epidemics of all intensities present in this study and for markets with varying levels of DON and TW stringency, MR cultivars were always at least as profitable as $\mathrm{S}$ cultivars. In some situations where DON was elevated and buyers were interested in wheat for flour, planting MR cultivars was necessary for profitability in addition to a fungicide. This result is noteworthy because, whereas the frequency of serious FHB epidemics varies within the SRWW region, there are increasingly few geographies where the risk of a damaging epidemic is negligible (McMullen et al. 2012; authors' personal observations). Even tillage was recently found to provide a lower degree of protection from scab (Bergstrom et al. 2013) than previously shown (Dill-Macky and Jones 2000), presumably due to the increased abundance of Fusarium spores coupled with their capacity for movement over substantial distances. For this reason, selection of FHBresistant cultivars has become more important in every SRWW environment, because it is a major determinant of profitability that cannot be adjusted if conditions turn out to be favorable for FHB.

An accurate prediction at early flowering of FHB incidence and harvest-ripe DON levels is valuable no matter the grain market. In the second approach to analyzing our data, we separated cultivar-location combinations by level of forecasted risk in order to determine the relative profitability of interpreting medium or high risk as a "do spray" recommendation and low risk as a "do not spray" recommendation. A number of combinations that developed high levels of FHB and DON were forecasted to have low risk and, conversely, combinations with low levels of FHB and DON were forecasted to have medium or high risk. If a successful prediction is defined as identifying when $>10 \%$ index would result, the resulting distribution of actual index values showed a sensitivity (positives correctly identified) of $40 \%$ and a specificity (negatives correctly identified) of $53 \%$. These levels were lower than the average performance of the risk model as indicated at the web site. The corresponding DON levels were in line with these low sensitivity and specificity rates. However, caution must be taken with interpretation, given the relatively small total sample and the unbalanced "do spray" versus "do not spray" sample sizes.

When it came to the profitability of fungicide decisions based on the risk forecast, our results illustrated the difficulty of making a profitable choice well before disease symptoms are visible and DON concentrations can be measured. We concluded that the risk model could not be used to accurately predict whether a fungicide applied in our environments would be profitable in a given market or how that might differ for MR versus S cultivars. A larger dataset should help with the problem of unbalance but it appears that, at least in this case, final outcomes in DON, yield, and TW were influenced by many factors not captured in the risk forecast at flowering.

In addition to showing the difficulties in using predicted risk, these data also illustrate the difficulty of using FHB symptoms to forecast DON levels at harvest. Our results are in line with metaanalyses showing that environment affects the slope of the relationship of index to DON (Paul et al. 2005, 2006). One reason for the divergence of forecasted and ultimate DON levels may be varying amounts of postflowering moisture, which has been shown to increase 
FHB severity and DON (Cowger et al. 2009) although, for our data, there was no correspondence between postanthesis precipitation and mean grain DON (Table 3). This study illustrates the gamble that occurs when making fungicide decisions based on a risk forecast that does not predict final grain DON.

The analysis based on mean environmental DON led to several conclusions: (i) there was no penalty for planting MR cultivars; (ii) a fungicide application could, in some circumstances, expand market options; (iii) if risk was medium or high, fungicides applied to MR cultivars tended to increase profits in the flexible market; and (iv) selling grain from $\mathrm{S}$ varieties to the flour market was unlikely to be profitable under any conditions.

Recommendations for FHB management in this geographic region should be explicitly market based. For the feed-grain market, a grower wishing to minimize unnecessary work and expense at flowering might do best by growing an MR cultivar and leaving it untreated. In most years, when DON $<4 \mu \mathrm{g} \mathrm{g}^{-1}$, this would result in maximum profit. Our data suggest that, even in a high-DON year, this strategy would result in profits equal to growing an S cultivar and applying a fungicide to it. Growers would benefit if they could predict at flowering whether DON levels were going to be not merely intermediate but high, so that a fungicide could be profitably applied to that MR cultivar. For growers selling to the flexible and flour-only markets, growing an MR cultivar and treating it with a fungicide when FHB is a threat is the scenario most likely to lead to a profit.

This study had a single high-DON environment and, thus, no conclusions can be drawn that contrast high-DON with medium- or low-DON environments. It was also not primarily designed to compare Caramba with Prosaro. The yield and DON differences observed between those products in the high-DON scenario were based on a single environment. In medium-DON environments, there was only one significant difference between the products and that was for yield of $\mathrm{S}$ varieties.

Our results illustrate the importance of taking relevant markets into account when estimating profitability of integrated disease management techniques. Small-grain growers need a market-based approach to management because they must make complex decisions on where to sell their crop based on transportation distance, crop quality, mycotoxin content, expected grading and dockage practices, and other factors. This approach likely has relevance beyond the FHB-wheat pathosystem.

Our work joins that of others who have considered profitability of fungicide applications; that is, to dry bean (Phaseolus vulgaris L.) under varying levels of white mold pressure (caused by Sclerotinia sclerotiorum (Lib.)) (Ramasubramaniam et al. 2008) or to maize attacked by gray leaf spot (caused by Cercospora zeae-maydis) (Munkvold et al. 2001). However, particular features of the FHB-wheat pathosystem that should be taken into account include the following: (i) both host resistance and fungicide efficacy are partial; (ii) spray decisions must be taken 2 to 3 weeks before disease symptoms appear, making accurate risk forecasts crucial; and (iii) prices differ significantly depending on end-use and quality. Other field crops where resistance is partial and fungicide profitability is sometimes marginal, such as pulse crops infected by Ascochyta blight (Davidson and Kimber 2007), might benefit from an approach similar to ours.

In conclusion, our results underscored that wheat cultivar resistance to FHB was important for profitability, an FHB-targeted fungicide expanded market options when risk was moderate or high, and recommendations for managing FHB need to take market type into consideration. Our study illustrated how fungicide decisionmaking is complicated by the factors that reduce accuracy of risk forecasting. The results highlighted how a forecasting tool that could accurately predict grain DON would be helpful, although the effects of deploying such a tool are complicated by the difficulty of attaining accuracy at the per-field level. Because FHB risk can be moderate or high in any given year throughout the SRWW region, the expanded use of MR cultivars is a necessary foundation of a profitable integrated management strategy.

\section{ACKNOWLEDGMENTS}

We thank A. Gardner and G. Ambrose for planting and managing field experiments; S. Crawford, Pennsylvania State University, for considerable assistance with risk forecasts; A. Hiatt, State Climate Office of North Carolina, North Carolina State University, for excellent assistance with weather data; Y. Dong, University of Minnesota, for providing DON analyses; and J. Ozkurt and R. Parks for technical assistance.

\section{LITERATURE CITED}

Bergstrom, G. C., Cummings, J. A., Waxman, K. D., Bradley, C. A., Wegulo, S. N., Hazelrigg, A. L., Hershman, D. E., Nagelkirk, M., and Sweets, L. E. 2013. Effects of local corn debris management on FHB and DON levels in seventeen U.S. wheat environments in 2011-2013. Pages 92-93 in: 2013 National Fusarium Head Blight Forum. S. M. Canty, A. Clark, Y. Salat, and D. A. Van Sanford, eds. U.S. Wheat \& Barley Scab Initiative, Milwaukee, WI.

Cowger, C., and Arellano, C. 2010. Plump kernels with high deoxynivalenol linked to late Gibberella zeae infection and marginal disease conditions in winter wheat. Phytopathology 100:719-728.

Cowger, C., Patton-Ozkurt, J., Brown-Guedira, G., and Perugini, L. 2009. Postanthesis moisture increased Fusarium head blight and deoxynivalenol levels in North Carolina winter wheat field experiment. Phytopathology 99:320-327.

Davidson, J. A., and Kimber, R. B. E. 2007. Integrated disease management of Ascochyta blight in pulse crops. Eur. J. Plant Pathol. 119:99-110.

Del Ponte, E. M., Fernandes, J. M. C., and Bergstrom, G. C. 2007. Influence of growth stage on Fusarium head blight and deoxynivalenol production in wheat. J. Phytopathol. 155:577-581.

Dill-Macky, R., and Jones, R. K. 2000. The effect of previous crop residues and tillage on Fusarium head blight of wheat. Plant Dis. 84:71-76.

Hart, L. P., Pestka, J. J., and Liu, M. T. 1984. Effect of kernel development and wet periods on production of deoxynivalenol in wheat infected with Gibberella zeae. Phytopathology 74:1415-1418.

Komada, H. 1976. A new selective medium for isolating Fusarium from natural soil. Proc. Am. Phytopathol. Soc. 3:221.

Littell, R. C., Milliken, G. A., Stroup, W. W., Wolfinger, R. D., and Schabenberber, O. 2006. SAS for Mixed Models, 2nd ed. SAS Institute, Inc., Cary, NC.

McMullen, M., Bergstrom, G., DeWolf, E. D., Dill-Macky, R., Hershman, D., Shaner, G., and Van Sanford, D. 2012. A unified effort to fight an enemy of wheat and barley: Fusarium head blight. Plant Dis. 96:1712-1728.

McMullen, M., Jones, R., and Gallenberg, D. 1997. Scab of wheat and barley: A re-emerging disease of devastating impact. Plant Dis. 81:1340-1348.

Munkvold, G. P., Martinson, C. A., Shriver, J. M., and Dixon, P. M. 2001. Probabilities for profitable fungicide use against gray leaf spot in hybrid maize. Phytopathology 91:477-484.

Parry, D. W., Jenkinson, P., and McLeod, L. 1995. Fusarium ear blight (scab) in small grain cereals-a review. Plant Pathol. 44:207-238.

Paul, P. A., Lipps, P. E., and Madden, L. V. 2005. Relationship between visual estimates of Fusarium head blight intensity and deoxynivalenol accumulation in harvested wheat grain: A meta-analysis. Phytopathology 95:1225-1236.

Paul, P. A., Lipps, P. E., and Madden, L. V. 2006. Meta-analysis of regression coefficients for the relationship between Fusarium head blight and deoxynivalenol content of wheat. Phytopathology 96:951-961.

Paul, P. A., McMullen, M., Hershman, D. E., and Madden, L. V. 2010. Metaanalysis of the effects of triazole-based fungicides on wheat yield and test weight as influenced by Fusarium head blight intensity. Phytopathology 100:160-171.

Ramasubramaniam, H., del Río Mendoza, L. E., and Bradley, C. A. 2008. Estimates of yield and economic losses associated with white mold of rainfed dry bean in North Dakota. Agron. J. 100:315-319.

Salgado, J. D., Madden, L. V., and Paul, P. A. 2015. Quantifying the effects of Fusarium head blight on grain yield and test weight in soft red winter wheat. Phytopathology 105:295-306.

Saxton, A. M. 1998. A macro for converting mean separation output to letter groupings in Proc Mixed. Pages 1243-1246 in: SAS Conf. Proc. 23rd SAS Users Group Int. SAS Institute, Cary, NC.

Schmale, D. G., III, and Bergstrom, G. C. 2003. Fusarium head blight. Online publication. Plant Health Instruct. doi:10.1094/PHI-I-2003-0612-01

Weisz, R., Cowger, C., Ambrose, G., and Gardner, A. 2011. Multiple midAtlantic field experiments show no economic benefit to fungicide application when fungal disease is absent in winter wheat. Phytopathology 101:323-333.

Willyerd, K. T., Li, C., Madden, L. V., Bradley, C. A., Bergstrom, G. C., Sweets, L. E., McMullen, M., Ransom, J. K., Osborne, L., Wegulo, S. N., Hershman, D. E., Wise, K., Bockus, W. W., Groth, D., Dill-Macky, R., Milus, E., Esker, P. D., Waxman, K. D., Adee, E. A., Ebelhar, S. E., Young, B. G., and Paul, P. A. 2012. Efficacy and stability of integrating fungicide and cultivar resistance to manage Fusarium head blight and deoxynivalenol in wheat. Plant Dis. 96:957-967. 